\title{
鉱物の弾性波速度および減衰特性を 測定する新しい装置の試作
}

\author{
東京大学地震研究所 藤 沢 英 幸 \\ 気象大学校木下肇・鉢嶺 猛 \\ (昭和 48 年 10 月 18 日受理)
}

\section{New Apparatus for Measurements of Velocity and Attenuation of Elastic Waves in Minerals}

\author{
Hideyuki FuJISAWA \\ Earthquake Research Institute, University of Tokyo \\ Hajimu KInoshita and Takeshi Hachimine \\ Meteorological College \\ (Received October 18, 1973)
}

\begin{abstract}
Electronic circuits for the measurements of velocity and attenuation of elastic waves are outlined. Two modifications are proposed. These are essentially apparatuses for the pulse-superposition method and used for the measurements in minerals. First of them gives output voltage of about $60(\mathrm{P}-\mathrm{P})$ of RF burst with varying carrier frequency of $10-50 \mathrm{MHz}$. The other one provides a similar output with a fixed carrier frequency of $10 \mathrm{MHz}$. Latter one is advantageous for attenuation measurement due to easy impedance matching of whole system for detection of very weak reflection of waves.

Since a principle of this sort of circuits are well known, the present paper will provide only a practical guide for construction of the circuits.
\end{abstract}

\section{§1.はじめに}

固体中を伝播する音波の速度を精密に測定する方法の一つに，パルス重ね合わせ法［例えば， MCSKIMIN (1961)] がある.そして，このパルス重ね合わせ法に用いられる装置は，そのまま 音波の減衰の測定に用いる事ができる。しかしながら，この測定法に必要な諸種の電子装置の うち，その中心をなすパルス発生器関係は，構成が複雑で製作がむずかしく，入手困難であつ た、筆者らは，最近著しく発達をとげた各種固体電子素子，特にディジタル集積回路と高周波 高出力トランジスタを活用し, 回路を簡単化し, 安価で, 素人にも製作でき, しかも高性能の 装置の製作に成功した. 
また，ディジタル集積回路を用いる目的は，単に，回路を簡単化するためのみではない。デ イジタル集積回路によつて，パルスを計数的に処理し，パルスを適当なタイミングで，必要な 個数だけ発生させるといらことが，特別な技術なしに可能になるからである．今回製作した二 種の装置の一つでは, このディジタル波数操作を採用している.

\section{§ 2. 構 成}

Fig. 1 は，本装置のブロック図である．まず，試料を中心として全体を二つに分け，前段 のパルス発生器関係の機能を Fig. 1 に即して簡単に述べる。 パルス発生器 (Pulse Generator) で矩形パルスを発生させる，このパルスのくり返し周波数は，前段の発振器 (CW Oscillator) (または内部発振器）の周波数によつて決められる。このパルスにより，次段の高周波パルス 発生器 (RF Pulse Gated Oscillator) が駆動される. 高周波パルス発生器は, 矩形パルスが 働いている時だけ発振をくり返し，断続的に高周波を発振する（後述の FKH-II では，多少 事情が異なるが，原理的には全く同じ)，パルス重ね合わせ法による測定の分解能の一部は， Fig. 1 に示されたシステムのらち，パルス発生器関係の性能に負うている．即ち，高周波パ ルスの立上り，立下りの鋭さ，実用上の最小パルス幅等が重要な要素となる：今回は，このパ ルス発生器関係について, 多少性能の異なる二種の装置を試作した (FKH-I, FKH-II). 以下 にその特徴を述べる。

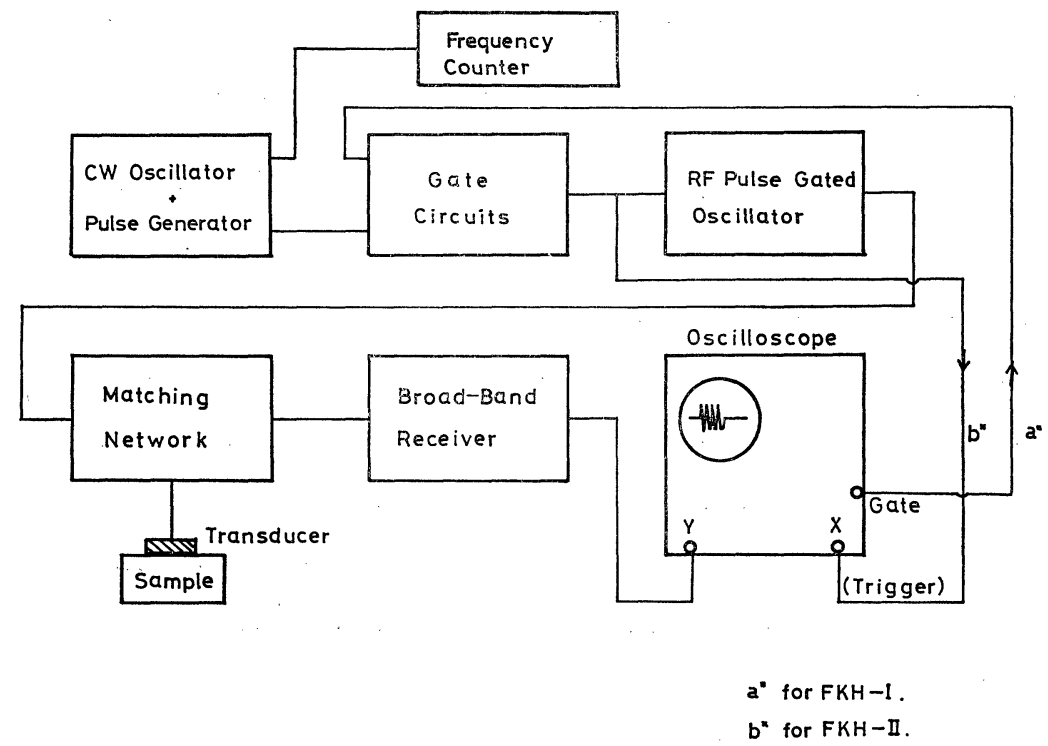

Fig. 1. Block diagram of the equipment. 
FKH-I： 高周波発振に LC 発振回路を用い，搬送波周波数を $10 \sim 50 \mathrm{MHz}$ の範囲で可变に した. パルス幅可変, 遅延調整可能. 出力 $(\mathrm{AMOP})$ は, ピーク值 $(\mathrm{P}-\mathrm{P})$ で $60 \mathrm{~V}$ 程度である，この装置の欠点は，高周波パルスの立下りが完全でなく，余韻(残留 振動）が存在し，これが，試料からの反射波の時間間隔が短い場合（つまり，試料 の音波速度が大きいか，またはその形が小さい場合)，余韻と反射波が重なつて， 測定の障害になることである.

FKH-II：この機種は, 三つの特徵を持つている. 第一に, 内部に, くり返し周期発生用の安 定な水晶発振回路と分周回路を持つていること，第二に，ディジタル集積回路によ つてパルスの波数を計数的に処理していること，第三に，高周波の発振に水晶発振 回路を用いていること，したがつて，搬送波周波数は固定（現在，10 MHz）である. それ故インピーダンス整合も容易で，高周波パルスの波形のくずれも極めて少ない. 他の性能は, FKH-I とほ涪同じである。

実際の測定の場合, ブロック図の通りパルス発生器の出力 (AMOP) は, 直接受信側にも入 り，試料による反射波より振幅が圧倒的に大きいため，反射波の観測のさまたげになる。この

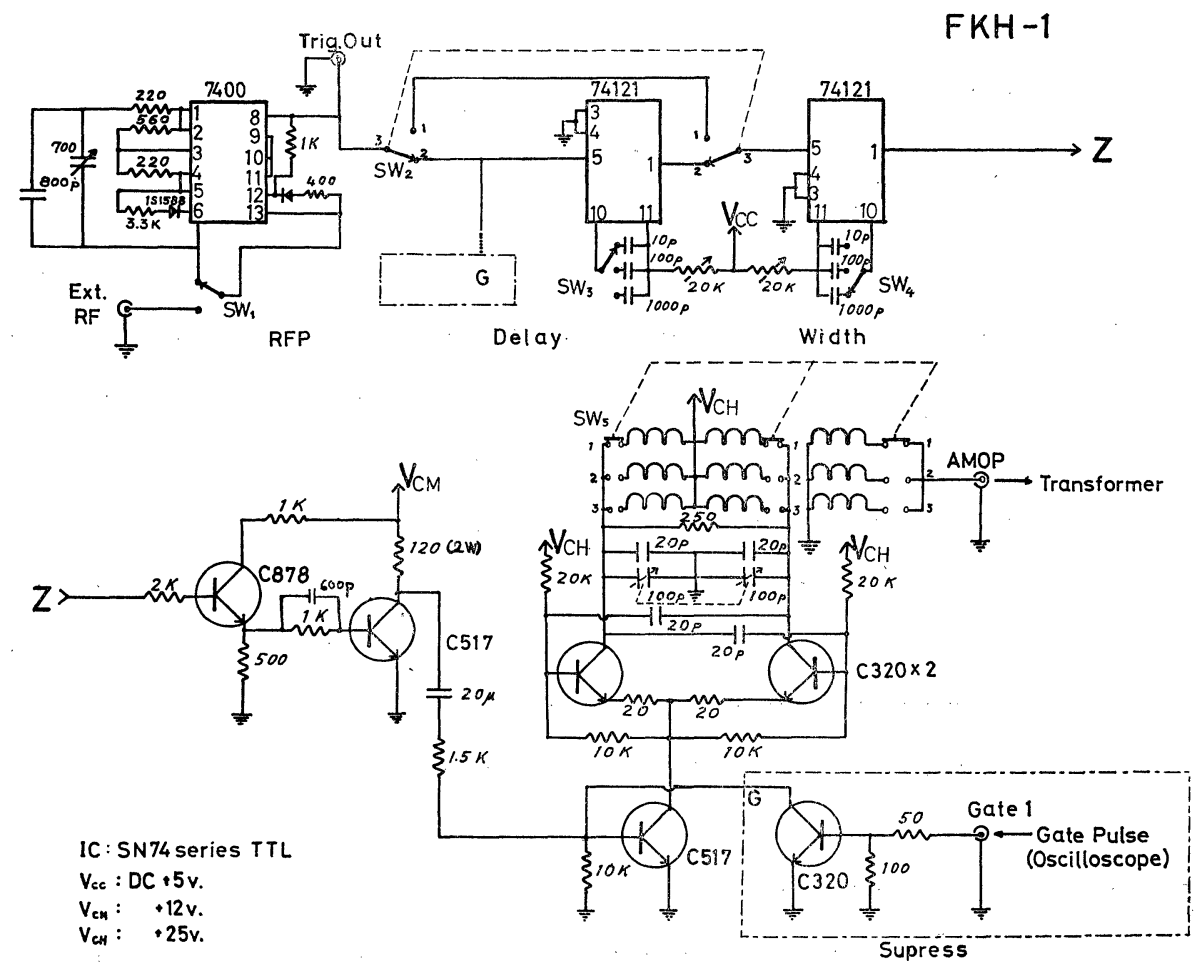

Fig. 2. Electronic circuit of FKH-I type equipment. 
困難を解決するため, 適当なタイミングで (AMOP) を消去する必要がある，FKH-II では， 内部の波数操作でこれが出来るが，FKH-I では，外部の抑制パルスと抑制回路を必要とする. その詳細は次節で述べる.

さて，次に，ブロック図で見る通り，インピーダンス整合用トランス (Transformer)，広帯 域前置増幅器（Broad-Sand Receiver）が介在してオシロスコープで反射波を観察する、トラ ンスと増幅器については, 次節で述べる。

\section{§3. 回路}

FKH-I： (Fig. 2, 上から下に向つて).

一段：矩形パルスの発生と，パルス幅・遅延の調整（出力 $\rightarrow \mathrm{Z})$. 簡単な発振回路を内蔵 している.

二段：矩形パルスを前二段で増幅. 三段目の 2 SC 517 にスイッチングを行なわせる. 2 SC 517 が on で, 2 SC 320 が導通すると発振回路が完結して, 高出力の高周波 パルスを出す $(\mathrm{AMOP})$. 終段は LC 発振回路であるから，C を変化させて搬送波 の周波数を変えることができる $(10 \sim 50 \mathrm{MHz})$. 実際の測定の場合，試料からの反 射波を見やすくするため，出力高周波パルス (AMOP) を適当なタイミングで消去 してやる必要がある. そのため, 普通, ブロック図でも示されている通りオシロス コープからの抑制パルスを用いて，抑制回路 (Fig. 2, Supress) の 2 SC 320 を on にして，2 SC 517 を駆動するパルスをアースしてやる．しかし，2 SC 320 の残留 抵抗の存在により，パルスを完全にはアースできない，それ故，最終的な出力に雑 音が残る.この雑音の振幅は，試料の反射波のそれと同程度なので測定のじゃまに なる.これを防ぐため，一点鎖線で囲んだ抑制回路 (Fig. 2, Supress) を Fig. 2 の第一段目の IC, 7400 と 74121 の間に入れて, 矩形パルスの発生そのものを押え てしまえば，回路は完全に働く、ただしこの場合，7400を破壊しないように，G に接続する部分に多少手を加える必要がある，この改良により，FKH-I の雑音は ほぼ完全に消去でき, 測定精度は一段と向上した。

ブロック図の Matching Network 以下の部分は FKH-II と共通で, Fig. 5 に 示されている.

FKH-II: (Figs. 3，4，5，上から下に).

一段： $10 \mathrm{MHz}$ の水晶発振器からの波を分周し，くり返し周波数 $10 \mathrm{MHz} \sim 100 \mathrm{KHz}$ の矩 形パルスを作る. (出力 $\rightarrow \mathrm{X}$ ). 


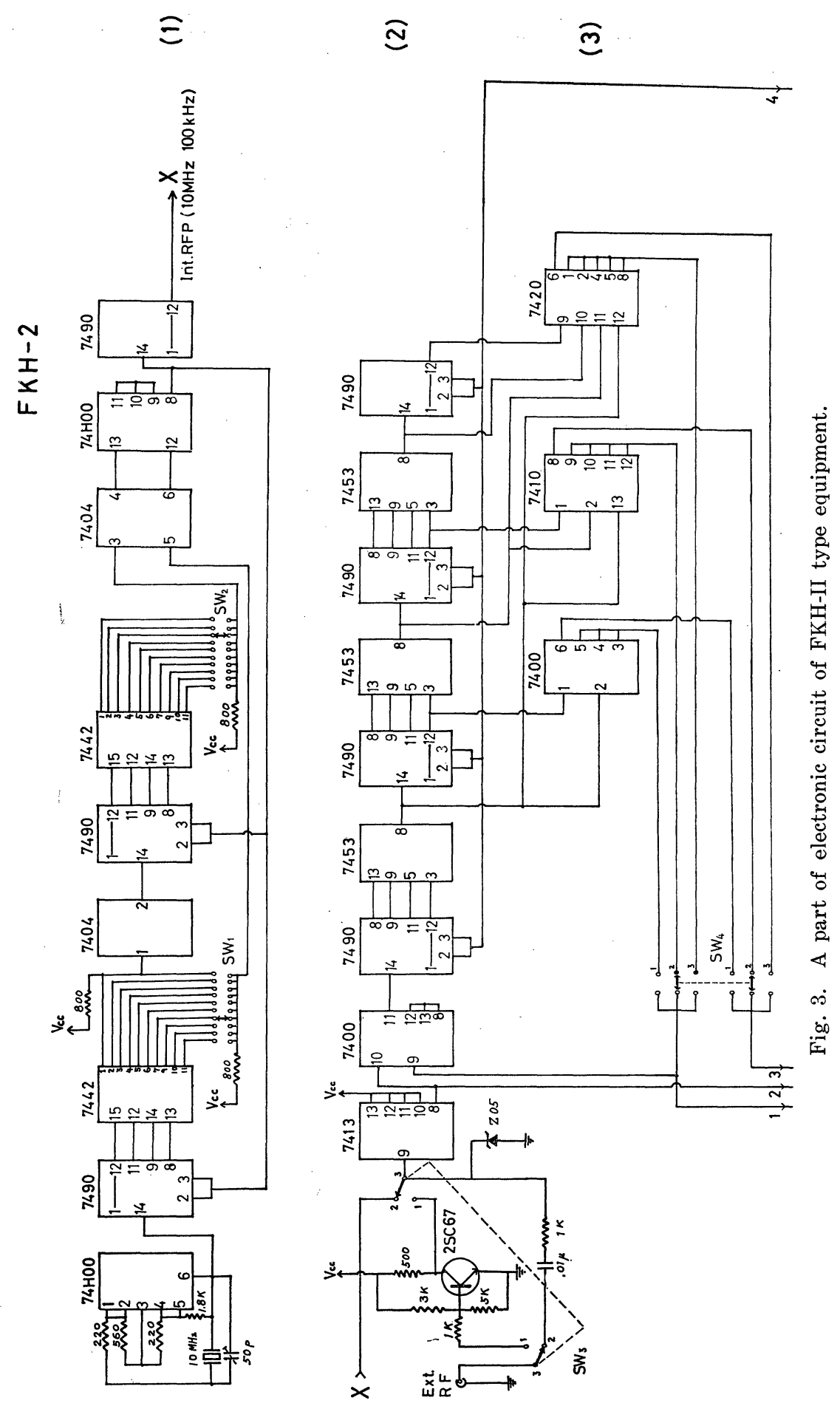




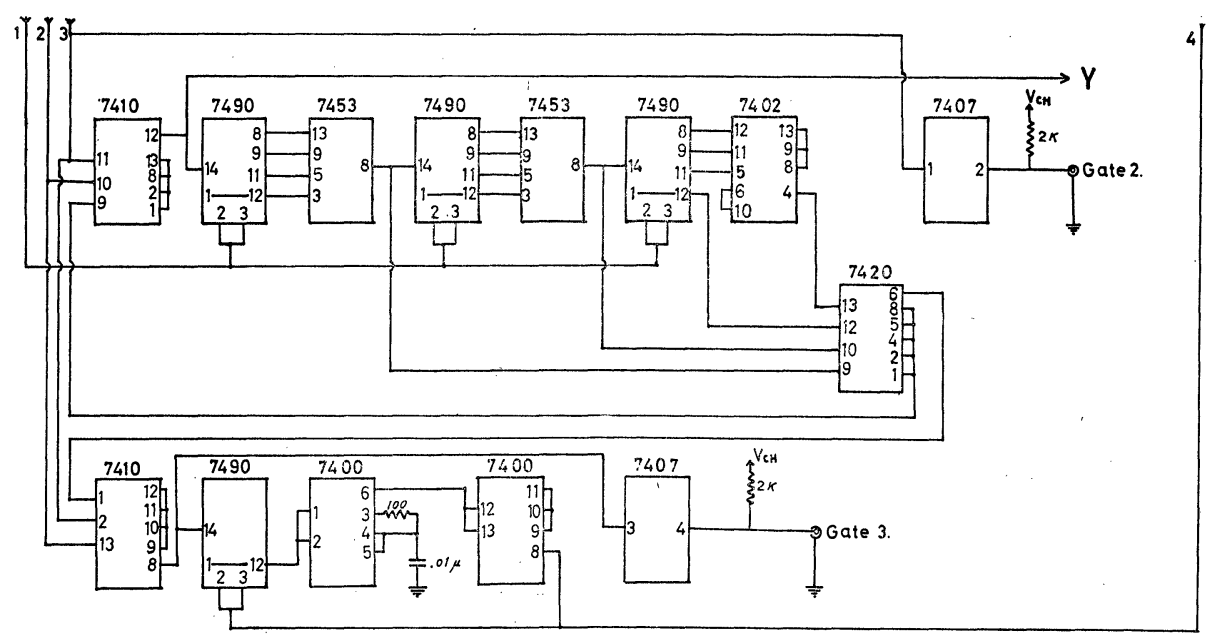

(4)

Fig. 4. A part of electronic circuit of FKH-II type equipment.

三〜矩形パルスを 100 ケ出した後, 空白時間をそれぞれ $10,100,1000$ パルス相当分 五段 : だけ設ける。この空白分の切換光は $\mathrm{SW}_{2}$ で行なら (出力 $\rightarrow \mathrm{Y}$ ).

六段：矩形パルスの幅と遅延調整を行なつた後, このパルスによりゲートを駆動して $10 \mathrm{MHz}$ の発振を行なわせる (出力 $\rightarrow \mathrm{Z}$ ).

七段の： 上段の出力を同調増幅器 (ブッシュプル) で増幅し, 高周波パルス出力 (AMOP) (AMOP) まで を取り出す。

FKH-II をI と同じに矩形波パルスによつて高周波発振を起させる場合には，五段目真中の 7400 を用いて外部パルスによるゲートの開閉をやつても良い.なお，図中＊の付いた部分は， 素子を意識的に悪用してパルスを歪ませ，正弦波を取り出したことを示したものである.

トラン：インピーダンス整合用の空気トランスは MATTABONI and SCHREIBER (1966) の ス データを参考にして製作した。ただし，形状，寸法は，同じ周波数範囲でも彼等の 原形とはかなり異なるものとなつた。

前置增：(Fig. 1, Broad-band Receiver). (Fig. 3, 下段参照). 搬送波周波数が 10 50 MHz と広く変動するので, 広帯域増幅用集積回路 SG $733 \mathrm{C}$ または相当品を用いて製作した。 SG $733 \mathrm{C}$ は, 帯域幅 $0 \sim 120 \mathrm{MHz}$, 入力感度数 $\mu \mathrm{V}$, 利得 $50 \mathrm{db}$, 差動型である. 実用上 $40 \mathrm{db}$ 程度で用いるのが安定で, これは電 源の性能にもよる。 さて, 実際の測定では, 数十ボルトの入力 (Transducer から 見て）高周波パルス（AMOP）自身も試料による反射波と同時に前置増幅器に入る 


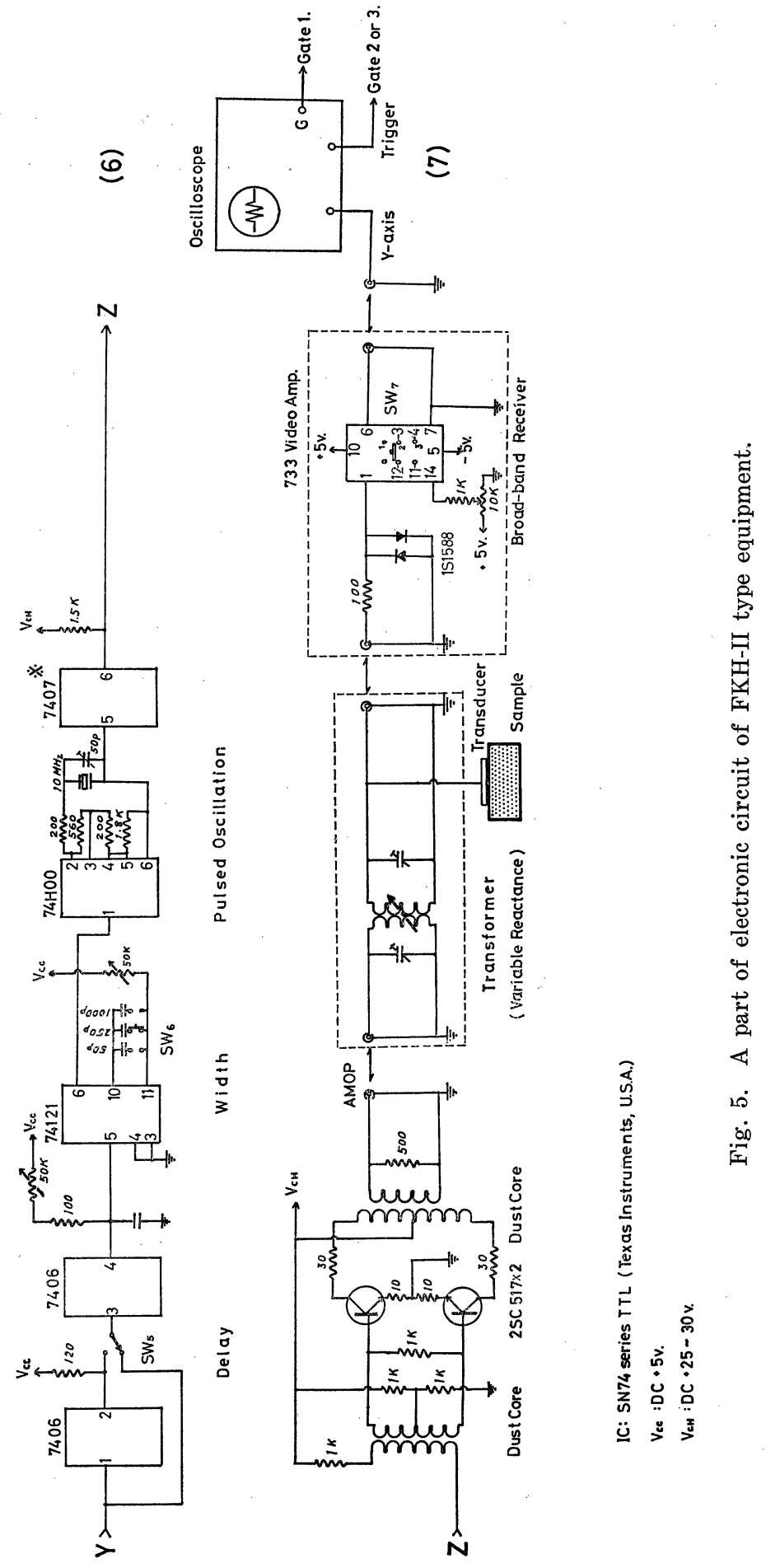


ので, (AMOP) の頭をシリコンダイオードで切つて $( \pm 0.7 \mathrm{~V}$ 内外 $)$ 増幅器を保護 している.

コイル：フェライトのトロイダルコア $(\sim 100 \mathrm{MHz}$, 内径 $10 \sim 20 \mathrm{~mm}$, 外径 $20 \sim 30 \mathrm{~mm}$, TDK およびトミタ電機製) に, $0.5 \sim 1.0 \phi$ 程度の銅線を数回 30 回程度まく. まき数は, 実験をくり返して最適なものをさがす.

\section{$\S 4$. 試 用結 果}

まず，速度の測定の精度について考える，測定装置の分解能のみならず，試料そのものの形 状誤差が全体の精度を左右する。したがつて，ここでは，今回試作した装置の分解能に限つて 考㝋る.

今までに行なつた測定は, 長さ $10 \mathrm{~mm}$ 程度の熔融石英を用いた極めて予備的な実験に限ら れている. この場合, くり返し周期を決定する発振器の精度 $\left(10^{-3}\right)$ が悪かつたため, 測定系 全体の精度がこれによつて決定されてしまつた，現在，この点を改良するため，周波数合成器 (精度 $\left.10^{-8}\right)$ を用いることにしている. しかし，たとえ高精度の発振器を用いたとしても，さ らに，実際にパルスが重なつた点を，いかに精度よく見分けるかといら問題が残る。この点を 改良するため「高精度タイミング回路」の製作を行なつている.さしあたつて，この装置の総 合的な精度の目標を $10^{-5}$ に抢き，さらに改良を目ざしている.

減衰特性の測定については，まだ試料と振動子の接着等の問題で定量的なことは言えないが， とにかく，現在程度のあらい実験でも，10 ケ以上の反射波を観測することができた。搬送波 周波数の範囲をさらに広げて，種々な減衰の機構について定量的な実験を行ならことを目ざし ている.

\section{謝 辞}

今回，回路を作るに当つて多くの助言と励をしを下さつた京都大学工学部の曾我助教授，名 古屋大学理学部の熊沢助教授, ならびに東京大学物性研究所の生島助教授に, この紙面を借り て深く感謝致します。

$$
\text { 文献 }
$$

Mattaboni, P., and E. Schreiber, 1966, Variable Air Transformer for Impedance Matching, Rev. Sci. Instr., 37, 1625-1626.

McSkimin, H. J., 1961, Pulse Superposition Method for Measuring Ultrasonic Wave Velocities in Solids, J. Acoust. Soc. Am., 33, 12-16. 